\title{
FEMALE EARNINGS AND DIVORCE RATES: SOME AUSTRALIAN EVIDENCE
}

\author{
Bruce Phillips and William Griffiths \\ University of Melbourne
}

\begin{abstract}
The purpose of this paper is to examine whether female earnings have influenced divorce rates in Australia, using state-level data for the past four decades. Following a recent study by Ressler and Waters (2000), which concludes from comparable US data that female earnings and divorce rates may be jointly endogenous, initial testing is performed to identify whether female earnings can be treated as exogenous. A Hausman specification error test finds no evidence of a simultaneous relationship in the Australian data, in contrast to the findings of Ressler and Waters. The test result supports the hypothesis that other underlying factors affect female earnings, of which higher divorce rates are merely another symptom. A divorce rate equation is estimated. In accordance with much of the literature, the rise in female earnings over the past four decades is found to have increased Australian divorce rates.
\end{abstract}




\section{Introduction}

Marriage has long been a revered social institution. Often portrayed as the embodiment of commitment and devotion, it lays a foundation for lasting companionship and the rearing of children. Of the many aspects that generate the cherished notion of "family", few tend to be more important than marriage. Despite these traditional sentiments, the sanctity of marriage has been challenged in the past few decades, as the number of people marrying has stagnated and divorce rates have increased. The patterns of marriages and divorces in Australia from 1961 are illustrated in Figure 1.

There are common causal factors for changes in trends to marry and divorce. However, the rise in marriage breakdown has typically attracted more focus because of the greater problems it is perceived to create. Depression and other psychiatric problems, social withdrawal, child abuse, and drug use have all been mooted as consequences of family failure (Pell 2001, p15).

\section{Figure 1}

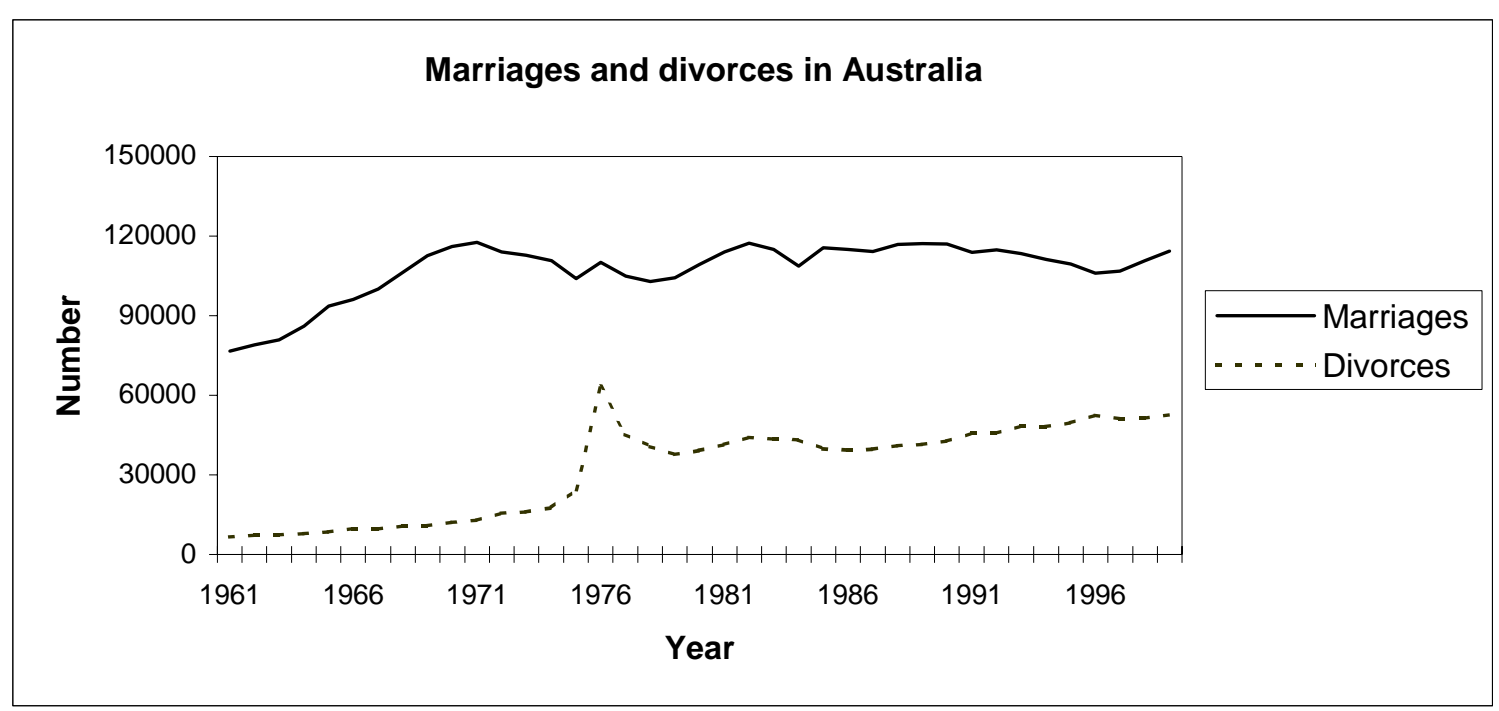

Source: Australian Bureau of Statistics, Marriages and Divorces, Canberra, 1995; 1999. 
Given these issues, it is not surprising that divorce has come to the attention of an economic profession increasingly ambitious to apply economic theory to explain behaviour outside the monetary market sector. During the past three decades, much empirical literature has emerged testing and refining Becker's (1973) seminal paper propounding a theory of marriage consistent with other decision-making methodology. By assuming various characteristics of the marriage 'market', Becker derives several conclusions about 'gains from marriage'. Such gains arise from the division of labour between the husband and wife in market and non-market work, and 'marriage' capital. Specialisation gains result in part from the male-female wage differential. 'Marriage' capital, or non-transferable commodities produced in a household, similarly enlarges these gains.

Becker, Landes and Michael (1977) extend this theory and test its pertinence using 1967 US census data. Rising female wages are found to increase the probability of divorce. Many subsequent studies, including Smith (1997), also find that higher women earnings were positively related to divorce rates. By concluding that state population densities affect divorce rates among 'farm' marriages, Sander (1985) infers that the divorce rate is significantly and substantially affected by the earning capacity of women in the marketplace. Lower population densities are thought to imply greater isolation for farm families and hence reduce the ability of 'farm' wives to reach working premises. The literature does not entirely support economic explanations of divorce, however. Hoffman and Duncan (1995) conclude that divorce rates are driven by changes in behaviour rather than economic factors. Analysing first marriages begun in the US between 1967 and 1983, the authors find male incomes, wages and welfare payments largely irrelevant to marital instability. 
A continuing issue of concern has been the possible endogeneity of various factors modelled in divorce equations. Johnson and Skinner (1986) test whether the labour supply of married women and the future probability of divorce are jointly determined by using a simultaneous equations model on 1972 data. They find that married women expecting divorce do indeed increase their labour market participation, but that higher participation in the job market itself does not affect the probability of divorce.

Using state-level U.S. Census data, collected at four different census times, Ressler and Waters (2000) adopt a simultaneous equations model with the divorce rate and female earnings as the jointly determined variables. Apart from divorce rates being influenced by higher female wages, the authors hypothesise that greater female earnings may be partly attributable to higher divorce rates. Ressler and Waters find that simultaneity does exist between divorce rates and female wages rates. From this result they infer that previous studies of divorce rates may suffer from simultaneity bias, overstating the positive impact of female earnings on divorce.

To our knowledge, the relationship between divorce rates and female earnings has yet to be explicitly investigated using Australian data. This paper adds to the literature by exploring possible links in Australian state-level data. We seek to determine whether growing female earnings have contributed to the rise in divorce evident in Figure 1. To do so, we evaluate whether female earnings are endogenous, hence testing the robustness of the findings of Ressler and Waters. We find that female earnings do appear to have influenced Australian divorce rates, but there is no evidence to suggest female earnings and divorce rates are jointly determined.

The remainder of the paper is organised as follows. In Section 2, models of the aggregate divorce rate and of average female earnings are devised. Section 3 contains 
a discussion of the econometric issues that arise and how these are addressed. Results from empirical tests and regressions are reported and analysed in Section 4. Some concluding remarks are provided in Section 5.

\section{The Model and Data}

Models of divorce rates and female earnings are developed in this section. The main focus is on estimation of an equation to explain divorce rates. A model for female earnings is constructed to test for simultaneity between divorce rates and female earnings and to provide suitable exogenous variables as instruments for this test. The two models are discussed in subsections 2.1 and 2.2, respectively. Each section contains details of the variables, and the data used to construct them; a comprehensive listing of data sources appears in the Appendix.

\section{$\underline{2.1 \quad \text { A model of divorce }}$}

According to Becker, Landes and Michael (1977), divorce is optimal when the sum of the values of post-divorce opportunities, including the option value of remarriage, net of divorce costs, exceeds the joint value of the current marriage. This rule requires that utility be transferable within the marriage. With costless bargaining, the gains to marriage can be redistributed in such a way that divorce only occurs when the joint benefits exceed the joint costs (Peters 1992 p437). In the notation of Weiss (1996 p112), divorce becomes optimal when:

$$
A_{w t}+A_{h t}-C_{t} \geq V_{t}\left(X_{h t}, X_{w t}, K_{t}, \theta_{t}\right)
$$

The value of the marriage $\left(V_{t}\right)$ is a function of the personal characteristics of the husband $\left(X_{h t}\right)$ and the wife $\left(X_{w t}\right)$, the level of marital capital, $K_{t}$, and the quality of the match, $\theta_{t}$. The variables $A_{w t}$ and $A_{h t}$ represent the outside opportunities of the 
wife and husband respectively; $C_{t}$ is the cost of divorce and includes legal costs, the loss of marriage specific capital, and personal costs. Divorce occurs endogenously whenever the couple cannot find an allocation within the marriage that dominates the divorce allocation (Weiss 1996 p110). Variables change in an unanticipated manner through the course of the marriage, as denoted by the subscript " $t$ ".

This model can be applied to test whether factors that might affect the value of each state impact on divorce activity. However, as Smith (1997 p535) has emphasised, the use of aggregate data precludes such models from including many relevant considerations. For couples, these include sexual satisfaction, courtship length and spousal differences in religion and education. Personal characteristics such as previous marital status, pre-marital pregnancy, and age at first marriage are also precluded from an aggregate framework. So precise measurement of $\theta_{t}$ becomes improbable. Instead, general characteristics of the populace must be used, from which inferences about the marital gains can be made according to economic theory.

In this paper we hypothesize that state-wide divorce rates can be expressed as:

$$
\begin{array}{r}
\text { DIVRATE }=f(F E M-E A R N, \text { REL-EARN }, \text { ASIAN }, \text { CATHOLIC, } \\
\text { MALE-UN, NUPBIRTHS, RURAL,WELFARE, QLD })
\end{array}
$$

A discussion of each of these variables and the data used follows. Data were compiled for each state in each of the five-yearly census years from 1961 to 1996 , making a total of 48 observations.

Ideally, the dependent variable would measure the number of divorce actions initiated in each census year. The only data available - the annual number of decrees absolute issued - is subject to inertia in delays in judicial and institutional processing (Smith 1997 p536). DIVRATE is the proportion of married people becoming divorced 
each census year. People designated as "permanently separated but not divorced" have been extracted from the married population and are essentially treated as divorcees. Further transformations used to derive DIVRATE values are described in the Appendix. The mean value of DIVRATE among the six states over the eight time periods is shown in Table 1. It peaked in 1976, declined sharply, then gradually increased again.

FEM-EARN, the average real weekly earnings of full-time, non-managerial female employees aged over 21, is perhaps the most representative of aggregate income measures. Managerial employees were excluded because their incomes can artificially inflate the average wage, as has been recently argued (Gordon and Robinson 2001). Nominal values have been deflated by the CPI in each state's capital city over the 1961-1996 period. FEM-EARN proxies for the conceptually desired variable - the average 'potential' market earnings of all married adult women (Smith 1997 p534). Higher female earnings are believed to diminish marital gains by reducing the demand for children and improving the opportunities for women outside marriage. For these reasons, improving economic conditions for women since the

Table 1. Sample means of variables in divorce-rate model averaged over states for each census year.

\begin{tabular}{ccccccccc}
\hline & 1961 & 1966 & 1971 & 1976 & 1981 & 1986 & 1991 & 1996 \\
\hline DIVRATE (\%) & 0.29 & 0.37 & 0.44 & 1.95 & 1.22 & 1.15 & 1.25 & 1.41 \\
FEM-EARN (\$) & 205.37 & 214.48 & 276.92 & 465.14 & 467.85 & 467.62 & 449.88 & 487.04 \\
REL-EARN (\%) & 60.60 & 63.72 & 66.53 & 86.97 & 87.18 & 96.45 & 97.92 & 89.68 \\
ASIAN (\%) & 0.68 & 0.79 & 1.14 & 1.47 & 2.03 & 2.70 & 3.39 & 3.82 \\
CATHOLIC (\%) & 23.08 & 24.31 & 25.06 & 23.70 & 23.85 & 23.85 & 25.11 & 24.61 \\
MALE-UN (\%) & 2.88 & 1.31 & 1.48 & 3.78 & 6.01 & 9.16 & 10.70 & 8.99 \\
NUPBIRTHS (\%) & 19.35 & 16.76 & 16.17 & 13.55 & 12.06 & 11.80 & 10.71 & 10.47 \\
RURAL (\%) & 21.89 & 20.14 & 17.19 & 16.42 & 16.62 & 16.87 & 17.11 & 16.27 \\
WELFARE (\%) & 21.86 & 35.51 & 32.53 & 33.56 & 31.73 & 36.33 & 39.53 & 35.29 \\
\hline
\end{tabular}


1960's have been cited as a significant contributor to the increasing divorce rate. FEM-EARN is therefore expected to have a positive coefficient. Its rise from 1961 is highlighted in Table 1.

Advantages accrue from a sexual division of labour within the marriage when male and female wage rates differ. A large relative male rate of pay encourages husbands to specialise in the market sector, with their wives specialising in household production. REL-EARN endeavours to capture specialisation gains by measuring the relative weekly earnings of full-time, non-managerial females to males. With exception of the years 1961 and 1966, when only total earnings were available, the earnings exclude overtime pay, to avoid any distortion being generated from males working longer hours. Higher relative earnings will erode gains from the sexual division of labour, implying that the value of the marriage declines. A positive sign is predicted on the coefficient of $R E L-E A R N$. It has experienced a similar rise to FEM$E A R N$ from 1961, apart from the decline that occurred in 1996. These features are shown in Table 1.

Empirical research suggests that people of different racial origin have varying propensities to divorce. Kidd (1995) and Sweezy and Tiefenthaler (1996) observe lower divorce hazard rates for people of Asian descent relative to other racial groups. Sweezy and Tiefenthaler (1996) find Asian women are more than twice as likely not to experience a divorce as white women. ASIAN is included to accommodate these differences. It is the proportion of the state population born in the Asian region, and is expected to negatively affect the divorce rate. ASIAN rises steadily over the years from 1961 to 1996 , as indicated in Table 1.

CATHOLIC is the proportion of the state population nominated as Catholic, including Roman Catholic. Faced with a disapproving religion, Catholics may face 
higher personal costs from divorce. Yet not all people designated as Catholics stringently follow its doctrine. CATHOLIC counts all people professing to be Catholic, although it would ideally include only those who are devout. Nevertheless, CATHOLIC is still a useful measure and should have a negative coefficient. Its mean has remained near $24 \%$ throughout the relevant period, as reported in Table 1, but there are state differences in the percentage.

Male unemployment unanticipated at the time of marriage causes a negative shock to the value of the married state (Becker, et al., $1977 \mathrm{p} 1161$ ). MALE-UN is the male unemployment rate at the time of each census. It is expected to have a positive influence on the divorce rate. As shown in Table 1, MALE-UN remained relatively low until 1976, rising steeply to a peak in 1991 before declining somewhat in 1996.

Marital-specific commodities are those assets whose value diminishes outside the marriage. The most cited example is young children. The economic theory predicts that couples with children have greater marital gains than their childless counterparts. A suitable regressor would therefore measure the percentage of marriages in each Australian state that contain a child from that union. Alterations to ABS measurements from 1961 to 1996 make this impossible to obtain. Instead, NUPBIRTHS is used as a very crude proxy. NUPBIRTHS is derived by summing the annual tally of nuptial births registered in each state over a period of four years, concluding with the census year. This aggregate is then averaged over the married population. At any census date, and assuming children remain in their state of birth, NUPBIRTHS is the number of nuptially-born children aged four or under per married person. It is expected to have a negative influence on DIVRATE. As illustrated in Table 1, the mean of NUPBIRTHS has steadily declined over the sample period. 
There are some problems with the variable NUPBIRTHS that deserve more acknowledgment. Firstly, the distribution of young children across marriages is disregarded. A state recording a higher NUPBIRTHS value may actually have fewer marriages containing children, if those children are concentrated in a smaller number of marriages. If Becker's (1977) hypothesis that the first two children discourage marriage more than additional children is accepted, then nuptial births that occur in marriages already containing children should not be weighted as heavily as first-child births. Secondly, NUPBIRTHS will include children conceived outside the marriage, but whose parents subsequently married following knowledge of the pregnancy. Accidental premarital conception increases the probability of dissolution because it raises the search cost of finding a suitable mate (Becker, et al., 1977 p1164). Therefore, unmarried prospective parents are more likely to accept marriage offers of lower value. This aspect will mitigate the anticipated negative relationship between DIVRATE and NUPBIRTHS.

Following the work of Sander (1985), RURAL is the proportion of the population living outside urban centres with 1000 people or more, as defined by the ABS. It proxies for the number of "farm" marriages in each state, a variable whose relevance stems from Sander's hypothesis that farm marriages were less likely to end in dissolution. Married women dwelling outside urban centres have limited exposure to market work, thereby reducing opportunities outside marriage. Couples in rural areas are also likely to exploit the gains from specialisation within marriage to a greater degree. For these reasons, it is anticipated that $R U R A L$ will have a negative impact on DIVRATE. However, this negative impact may decline as the number of people living in rural areas increases, as this may actually present greater opportunities outside the marriage for 'country' wives. $R U R A L$ is expected to have a 
negative but diminishing effect on the divorce rate. This effect can be captured by including linear and reciprocal terms, with both expected to have positive coefficients. From Table 1 we see that the RURAL average declined from 1961-76, thereafter increasing except for a small decline in 1996.

Welfare payments may encourage divorce by improving post-divorce opportunities. The Commonwealth Government assumed responsibility for the pension scheme for divorced women and their dependent children in June 1942. Although nominal payments spanning the desired period are therefore identical across states, payments in real terms and with regard to opportunity costs are dissimilar. Disparities arise in real values because of the unique CPI movements in each state. The value of pensions must also be assessed in a context mindful of the husband income they are likely to replace. The pension scheme considered is the maximum weekly payment to divorced and unemployed mothers with one child under five. WELFARE is this pension payment in real terms, as a percentage of the average "ordinary time" income of full-time adult non-managerial males in each state. It is expected to positively influence DIVRATE. The WELFARE mean jumped sharply upwards after 1961, but from then on fluctuated between $31 \%$ and $39 \%$, as indicated in Table 1.

State-specific cultural climates can be important determinant of regional propensities to divorce. Ressler and Waters (2000) find that a dummy variable taking the value of 1 for deeply religious states and 0 otherwise is significant in their model. Queensland is more conservative than other Australian states, which may lead it to have lower divorce rates than elsewhere. $Q L D$ is a dummy variable equal to 1 if the state is Queensland and 0 otherwise. 
The scarcity of useful observations encountered in this project make it imperative to include all possible comparable data. However, extending the study to include data from the 1961 and 1966 censuses raises some issues of concern in the sample composition. Aborigines were not officially recognised as Australian citizens until after 1967; censuses prior to that year exclude Aborigines from all published aggregate measures. It is worth considering the impact of this omission on the sample.

Some American studies report that African-Americans have a higher probability of divorce than the white population. Johnson and Skinner (1986) found that non-whites have a higher divorce rate by roughly four percentage points, although this parameter was not significant. Such findings have been attributed to the increased marital instability that accompanies poorer living and working conditions. America's blacks and Australia's indigenous population share similar socio-economic characteristics in their respective countries: higher relative poverty and unemployment rates, with lower life expectancy. If such traits lead to divorce, then Australian Aborigines may have a higher divorce rate relative to the white population. Under such circumstances, the ratio of the population of Aboriginal descent would therefore be a valid regressor. The data set cannot accommodate such a variable. Instead, it is assumed that the impact of different Aboriginal populations on the divorce rate for each state is negligible, implying that pre-1967 data is comparable with the rest of the sample.

\section{$\underline{2.2 \text { A model of female earnings }}$}

An equation for female earnings is formulated to accommodate the possibility that divorce rates and female earnings are simultaneously determined. If female earnings is found to be endogenous in the divorce rate equation, then, to obtain consistent 
estimates, this equation needs to be estimated using a technique such as two-stage least squares or instrumental variables. It is hypothesised that:

FEM $-E A R N=f($ DIVRATE, EDUCATION, FEMALE-UN, FERTILITY, METRO, LABOURERS, SERVICE)

Assessing the simultaneity issue is equivalent to asking whether DIVRATE should appear in this equation. Ressler and Waters (2000) hypothesise that divorce leads to women being more career conscious, and thus higher earners. Accordingly, DIVRATE should positively influence FEM-EARN. There are counter arguments, however. While it may be true for some females that divorce encourages a career focus, for others divorce may stunt professional careers as single mothers may be forced to leave work to care for children. Also, Ressler and Waters' contention implies that a female divorcee would earn more than an identical but married counterpart; that female divorcees and childless wives should have substantial differences in income. Overlooked is the possibility that FEM-EARN and DIVRATE are influenced by common causal factors. A prime example is children. It may be an absence of children that allow women to focus on careers, not divorce. If the presence of children affects both female earnings and the likelihood of divorce, then divorced women may be earning more because they have no children, which contributed to their divorced status. Conversely, married women may remain married because they have children, increasing marital gains but reducing their income. So DIVRATE may not actually affect FEM-EARN; rather, any underlying relationship could be entirely driven by other considerations.

EDUCATION is the proportion of the female population with a bachelor or higher degree. Its 1961 value was unavailable and was estimated by assuming the percentage change from 1961 to 1966 was the same as that from 1966 to 1971. 
Economic theory dictates that academic qualifications increase the earning potential of workers. The sharp increase in EDUCATION from 1961 to 1996 shown in Table 2 is expected to have contributed positively to the rise in FEM-EARN.

FEMALE-UN is the unemployment rate of the female workforce at the time of each census. A high unemployment rate could reflect an excess supply of labour, which would decrease FEM-EARN. As shown in Table 2, FEM-UN remained steady until 1971, increased through to 1986, and then declined gradually.

Because women who give birth must withdraw from the workforce, childbirth is viewed as sacrificial in terms of income. FERTILITY is the number of births in the census year divided by the female population of that state. As demonstrated in Table 2, the mean of FERTILITY has declined strongly over the sample period.

Greater access to employment opportunities increases earning potential. METRO is the proportion of the state female population living in settlements containing a population of greater than 100 000, accordingly to ABS definitions. After an increase in 1961, the mean of METRO stabilised at around 5859\%, as shown in Table 2. METRO should have a positive influence on FEM-EARN.

Table 2. Sample means of variables in female-earnings model averaged over states for each census year.

\begin{tabular}{ccccccccc}
\hline & 1961 & 1966 & 1971 & 1976 & 1981 & 1986 & 1991 & 1996 \\
\hline FEM-EARN (\$) & 205.37 & 214.48 & 276.92 & 465.14 & 467.85 & 467.62 & 449.88 & 487.04 \\
DIVRATE (\%) & 0.29 & 0.37 & 0.44 & 1.95 & 1.22 & 1.15 & 1.25 & 1.41 \\
EDUCATION (\%) & 1.71 & 1.96 & 2.65 & 3.58 & 6.39 & 8.54 & 13.02 & 18.51 \\
FEM-UN (\%) & 2.82 & 2.36 & 2.18 & 4.88 & 7.23 & 9.19 & 9.04 & 7.98 \\
FERTILITY & 0.0474 & 0.0397 & 0.0433 & 0.0335 & 0.0326 & 0.0312 & 0.0300 & 0.0278 \\
METRO (\%) & 53.50 & 58.16 & 59.32 & 59.80 & 58.67 & 57.89 & 58.19 & 58.09 \\
LABOURERS (\%) & 14.11 & 13.20 & 11.54 & 9.25 & 7.96 & 13.87 & 9.67 & 11.51 \\
SERVICE (\%) & 17.54 & 16.50 & 16.33 & 14.77 & 14.75 & 15.57 & 15.46 & 21.41 \\
\hline
\end{tabular}


Earnings differ across occupational groups. In the last three decades women have increasingly secured high-earning occupations, causing an increase in FEM$E A R N$. High wage jobs typically refer to professional and managerial positions. The proportion of women in these occupations are not included as regressors because there will be a high degree of multicollinearity between these variables and EDUCATION. Women have increased their representation in high paying jobs substantially because they have accumulated greater educational qualifications. Hence EDUCATION will capture most all of the effects of additional women being employed in high wage occupational groups.

The same cannot be said for low wage occupations, which the model endeavours to represent with LABOURERS and SERVICE. LABOURERS is the proportion of the state female workforce employed as labourers and basic production process workers. SERVICE measures those working in rudimentary service occupations, including maids, cooks and waitresses. Both of these variables are expected to have a negative impact on FEM-EARN. The average of LABOURERS declined steadily from 1961 until 1981, and has fluctuated since. New standards for job classifications that began in 1986 (discussed below) might explain these variations. The mean of SERVICE fell slightly from 1961 to 1991 but experienced a strong rise in 1996.

Classifications for occupational groups changed twice in the period under scrutiny, with different occupational groups used in Census publications from 19611981, 1986-91 and 1996. The procedure for creating a coherent set of data is described in the Appendix. 


\section{Econometric Issues}

The data set is a pooled one containing observations on 6 states from 8 censuses. This pooled nature of the data raises questions about choice of a model specification and statistical assumptions to accommodate the different time series and cross-sectional components. For some of the possible alternatives, see Griffiths et al (1993). With a total of only 48 observations, the scope for sophisticated modelling is limited. In each equation the equation errors were assumed to be uncorrelated with zero mean and with a variance constant over both time and states. Intercept dummy variables were used to model differences over time in the DIVRATE equation and differences over time and states in the FEM-EARN equation.

In the DIVRATE equation there are likely to be influences not captured by other regressors that cause the divorce rate to change over time. The social stigma attached to divorce has decreased since the 1960's, yet this change in attitude cannot be clearly quantified a priori. Time varying intercept terms are appropriate to capture this change. Intercept values are assumed constant across states in the DIVRATE equation, with the exception of Queensland, as discussed previously.

State intercept dummies are included in the FEM-EARN equation as FEMEARN might differ across states for reasons other than those explained by the quantitative regressors. Victoria and New South Wales have capital cities that far exceed the size of those in Tasmania, South Australia and Western Australia. The largest firms tend to centre their Australian operations in Sydney or Melbourne. The higher wages typically available as a result may boost female earnings compared to other states. Some women with greater earning capacity may actually relocate to New South Wales and Victoria for these reasons. METRO makes no allowance for the overall magnitude of metropolitan centres other than having population of greater than 
100,000. Industry structures also differ across states. Female earnings could partly depend on the performances of industries that are unevenly distributed across states. Factors such as these should theoretically lead to different intercept terms across states; dummy variables for each state are thus appropriate. Ressler and Waters (2000) excluded state dummies from their female earnings equation, and their results may be contingent on this omission.

The possible endogeneity of FEM-EARN in the DIVRATE equation is tested using a Hausman specification error test. Various versions of this test are available. The one adopted is that described by Maddala (1992 p395). The predicted values of FEM-EARN, denoted by $\sim F E M-E A R N$, are obtained from its reduced form equation and then used as a regressor along with the original explanatory variables in the estimation of the DIVRATE equation. Significance of the $t$-statistic for the $\sim F E M$ EARN coefficient suggests there is a simultaneity problem. A lack of significance means there is no firm evidence that FEM-EARN is endogenous and hence no evidence that DIVRATE should be included in the FEM-EARN equation.

\section{Results}

The first result examined was that for the Hausman specification test. The $t$-value on the variable $\sim F E M$-EARN was -0.0072 , with a corresponding $p$-value of 0.99 . Thus, there is no evidence to suggest that FEM-EARN is endogenous. This finding of no simultaneity is incongruent with the results of Ressler and Waters (2000). Given that Ressler and Waters excluded state dummy variables in their FEM-EARN model, further testing was performed to see whether this difference may be the source of the conflicting conclusions. Intercept shifting, state dummy variables were dropped from the original FEM-EARN model to generate an alternate set of predicted values. When 
the Hausman specification error test was performed using these values, a $t$-value of $0.300 \quad(p$-value $=0.77)$ was obtained. The outcome of the test is robust to the exclusion of the state dummy variables. Thus, it was concluded that FEM-EARN could be treated as exogenous in the divorce rate equation, and this equation was estimated using ordinary least squares.

Table 3 contains least squares estimates of three versions of the divorce equation and the $t$-values corresponding to these estimates. In Regression 1 all variables discussed in Section 2 and all the time dummy variables are included. In Regression 2 the number of time dummy variables is reduced from 8 to 3 , so that the equation has a pre-1976 intercept, a 1976 intercept, and a post-1976 intercept. Regression 3 continues with the reduced number of intercepts and also excludes the variables ASIAN and WELFARE. In addition to the coefficient estimates, the Table contains the adjusted $R^{2}$ 's, the $F$-values for testing the null hypothesis that all slope coefficients are zero, Jarque-Bera values for testing normality of the errors, and the results from Ramsey RESET tests, testing for model misspecification by the addition of fitted squared predictions. These statistics show, respectively, the equations fit the data well, the null hypothesis of zero slope coefficients is rejected, there is no evidence against normality of the errors, and no obvious model misspecification.

In Regression 1 a relatively large number of coefficients is being estimated with a relatively small number of observations. Also, many variables will suffer from some degree of multicollinearity; NUPBIRTHS and FEM-EARN are examples. Thus, efficient estimation is difficult and this fact is reflected by small $t$-ratios on several of the coefficients. Two steps were undertaken to improve the efficiency of estimates by reducing the number of variables to be estimated. These two steps led to Regressions 
Table 3 Estimated equations for divorce rate

\begin{tabular}{|c|c|c|c|}
\hline Regressors & Regression 1 & Regression 2 & Regression 3 \\
\hline 1961 & $\begin{array}{l}-0.0041 \\
(-0.377)\end{array}$ & \multirow{3}{*}{$\begin{array}{l}0.0057 \\
(1.105)\end{array}$} & \multirow{3}{*}{$\begin{array}{l}0.0071 \\
(1.507)\end{array}$} \\
\hline 1966 & $\begin{array}{l}-0.0063 \\
(-0.413)\end{array}$ & & \\
\hline 1971 & $\begin{array}{l}-0.0065 \\
(-0.413)\end{array}$ & & \\
\hline 1976 & $\begin{array}{l}0.0045 \\
(0.231)\end{array}$ & $\begin{array}{l}0.0193 * * * \\
(3.290)\end{array}$ & $\begin{array}{c}0.0205 * * * \\
(3.734)\end{array}$ \\
\hline 1981 & $\begin{array}{l}-0.0037 \\
(-0.198)\end{array}$ & \multirow{4}{*}{$\begin{array}{l}0.0104 * \\
(1.819)\end{array}$} & \multirow{4}{*}{$\begin{array}{l}0.0115^{* *} \\
(2.108)\end{array}$} \\
\hline 1986 & $\begin{array}{l}-0.0054 \\
(-0.277)\end{array}$ & & \\
\hline 1991 & $\begin{array}{l}-0.0055 \\
(-0.276)\end{array}$ & & \\
\hline 1996 & $\begin{array}{l}-0.0046 \\
(-0.228)\end{array}$ & & \\
\hline FEM-EARN & $\begin{array}{l}0.2607 \\
(0.728)\end{array}$ & $\begin{array}{l}0.1567 * * \\
(2.119)\end{array}$ & $\begin{array}{l}0.1268 * * \\
(2.063)\end{array}$ \\
\hline$R E L-E A R N$ & $\begin{array}{l}-0.0154 \\
(-0.952)\end{array}$ & $\begin{array}{l}-0.0186 * * * \\
(-3.482)\end{array}$ & $\begin{array}{l}-0.0158 * * * \\
(-4.199)\end{array}$ \\
\hline ASIAN & $\begin{array}{l}-0.0072 \\
(-0.276)\end{array}$ & $\begin{array}{l}-0.0069) \\
(-0.406)\end{array}$ & - \\
\hline CATHOLIC & $\begin{array}{l}-0.0068 \\
(-0.822)\end{array}$ & $\begin{array}{l}-0.0064 \\
(-0.909)\end{array}$ & $\begin{array}{l}-0.0062 \\
(-1.087)\end{array}$ \\
\hline$M A L E-U N$ & $\begin{array}{l}0.0439 * * \\
(2.515)\end{array}$ & $\begin{array}{l}0.0378^{* * *} \\
(3.103)\end{array}$ & $\begin{array}{l}0.0325 * * * \\
(3.327)\end{array}$ \\
\hline NUPBIRTHS & $\begin{array}{l}-0.0035 \\
(-1.270)\end{array}$ & $\begin{array}{l}-0.0518 * * \\
(-2.495)\end{array}$ & $\begin{array}{l}-0.0641 * * * \\
(-4.985)\end{array}$ \\
\hline RURAL & $\begin{array}{l}0.0334 * * \\
(2.510)\end{array}$ & $\begin{array}{l}0.0384 * * * \\
(3.339)\end{array}$ & $\begin{array}{l}0.0419 * * * \\
(4.043)\end{array}$ \\
\hline $1 /(R U R A L)$ & $\begin{array}{l}0.0012 * * * \\
(3.007)\end{array}$ & $\begin{array}{l}0.0013 * * * \\
(3.476)\end{array}$ & $\begin{array}{l}0.0014 * * * \\
(3.755)\end{array}$ \\
\hline WELFARE & $\begin{array}{l}0.0227 \\
(0.542)\end{array}$ & $\begin{array}{l}0.0045 \\
(0.754)\end{array}$ & - \\
\hline$Q L D$ & $\begin{array}{l}-0.0006 \\
(-1.086) \\
\end{array}$ & $\begin{array}{l}-0.0007 \\
(-1.504)\end{array}$ & $\begin{array}{l}-0.0007 \\
(-1.609)\end{array}$ \\
\hline Adjusted $R^{2}$ & 0.9789 & 0.9801 & 0.9808 \\
\hline$F$-Statistic & 128.969 & 193.558 & 241.427 \\
\hline $\begin{array}{l}\text { Jarque-Bera } \\
(p \text { value })\end{array}$ & $\begin{array}{c}0.607 \\
(0.738)\end{array}$ & $\begin{array}{c}0.204 \\
(0.903)\end{array}$ & $\begin{array}{c}0.437 \\
(0.803)\end{array}$ \\
\hline $\begin{array}{l}\text { RESET } F \text { value } \\
\text { ( } p \text { value) }\end{array}$ & $\begin{array}{c}1.651 \\
(0.209)\end{array}$ & $\begin{array}{c}2.010 \\
(0.165)\end{array}$ & $\begin{array}{c}1.882 \\
(0.179)\end{array}$ \\
\hline
\end{tabular}

Notes: $t$-statistics in parentheses with:

$$
\begin{array}{ll}
* * * & =0.01 \text { level of significance } \\
* * & =0.05 \text { level of significance } \\
* & =0.1 \text { level of significance }
\end{array}
$$


2 and 3. First, Wald Tests were performed on the 1961 to 1996 dummy variables, to examine whether some time varying intercepts were statistically identical, and thus worthy of amalgamation. Second a "general to simple" approach to estimation was adopted. To overcome problems with omitted variable bias, regressors were not dropped from the equation on the basis of insignificance alone. Their theoretical foundation for inclusion and the adjusted $R^{2}$ resulting from their exclusion were also considered. This step dilutes the affect of multicollinearity as well as increasing the degrees of freedom.

The null hypothesis of the 1961, 1966 and 1971 intercept terms being equal could not be rejected at a $10 \%$ level of significance, with an $F$-statistic of 0.09 . Similarly, the null hypothesis of the 1981, 1986, 1991 and 1996 coefficients being identical could not be rejected. In that case, the $F$-statistic was 0.95 . These tests suggest that different intercepts exist for three time periods only: 1961-1971, 1976, and 1981-1996. This result is fitting, given 'no-fault' divorce was introduced throughout Australia in 1975. The 'no fault' divorce principle means divorce can be granted once applicants demonstrate the marriage has irretrievably broken down, usually evidenced by spouses living apart for 12 months.

Regression 2 displays results for the DIVRATE estimation when dummy variables with statistically identical coefficients have been consolidated into single terms. More efficient estimates are therefore obtained. Comparing the coefficients of the consolidated dummies for the 1961-71, 1976 and 1981-96 periods, it appears that liberalising divorce procedures caused a positive shock to the divorce rate. Smith (1997) observed similar outcomes in Britain, and hypothesised they were due to a clearance of long-dead marriages. The failure of the post-1976 intercept term to return to its earlier level indicates the new legislation has also had a long-run positive impact 
on divorce rates. Hence, the results support claims that the era of no-fault divorce has seen a new plateau in the incidence of divorce become established in Australia (Carmichael, et al, 1996 p4).

In Regression 2, the coefficients of ASIAN and WELFARE are not significantly different from zero, and their sequential exclusion from the equation led to increases in the adjusted $R^{2}$. Thus, they were omitted from the equation, leading to the results reported as Regression 3. ASIAN did have the anticipated negative coefficient, but its insignificance means this result only weakly supports the view that people of Asian descent have lower inclination to divorce compared to other racial groups. With respect to WELFARE, the literature reports mixed findings on the influence of such factors on divorce rates. Peters (1992), and Sweezy and Tiefenthaler (1996) both detail a negative but insignificant influence of welfare-type measures on divorce rates. Hoffman and Duncan (1995) find they have a positive but insignificant impact. Curiously, Ressler and Waters (2000) find that growing welfare payments had a negative and significant effect on divorce rates over the past four decades. Our results for WELFARE join most of these reports in inferring that welfare payments have had only a weak influence on marital instability.

In Regression 3, the coefficients of CATHOLIC and QLD remain insignificant, but they are retained because they have the anticipated signs and omitting them will lead to a reduction in the adjusted $R^{2}$. It is difficult to assess 'religiosity' by simply measuring the percentage of Catholics in a state. When modelling divorce hazard rates, Johnson and Skinner (1986) found an irregular affect from a 'Catholic' variable, although a 'frequent religious attendance' variable had a negative and significant impact. The mild evidence that $Q L D$ has a negative impact on divorce rates could be attributed to 'conservatism', but it also could be attributed to the fact that Queensland 
has an older population. A recurring finding in the literature is of higher relative divorce rates among those who marry at a young age. The higher probability of failure is attributed to each partner having inferior information concerning their spouse and their own needs. The information deficiency typically leads to 'young' marriages containing partners of less compatibility than marriages of older men and women. The variable $Q L D$ could be picking up this effect because of Queensland's older age profile.

Although FEM-EARN consistently has a positive coefficient, it only becomes significant once the intercept terms are consolidated. Regressions 2 and 3 show that FEM-EARN has a positive and significant impact on DIVRATE. Rising female earnings appear to have contributed to the increase in divorce in Australia. These results concur with common findings in the literature.

$R E L-E A R N$ has a coefficient significantly different from zero in Regressions 2 and 3, and a negative coefficient, implying that the rise in divorce has not been driven by greater sexual equality in earnings. The signs of the REL-EARN and FEM-EARN coefficients suggest that increasing independence of women in the form of higher real wages has been the major force behind marital instability. Diminishing specialisation gains from the division of labour actually appear to reduce the divorce rate, once we control for the presence of young children through the variable NUPBIRTHS.

NUPBIRTHS has a significant coefficient of expected sign. Using the more appealing variable of "the percentage of married couples in each state with children under six", Ressler and Waters (2000) obtain exactly the same result. It appears that despite being a crude proxy, NUPBIRTHS may accurately reflect the desired variable. Divorce rates appear to be positively influenced by the male unemployment rate, 
given that $M A L E-U N$ has a significant and positive coefficient in every regression. Studies using aggregate and micro-set data commonly find this result.

Both RURAL and (1/RURAL) have significant coefficients and the expected positive signs. The impact of RURAL on DIVRATE is a diminishing negative one as was hypothesized, up to the proportion $R U R A L=0.18$. Thereafter it is positive. This outcome can be explained by another characteristic of rural life that may lead to higher divorce rates. People living in rural areas face higher search costs when selecting a mate; their search will therefore be briefer and they may settle for a partner that is ultimately unsuitable. As noted by Sweezy and Teifenthaler (1996), the divorce-deterring impact of extra martial gains from rural living can be offset by the divorce-raising prospect of high search costs.

To ensure least squares would be an appropriate estimation technique for the divorce rate equation, we began this section by testing whether FEM-EARN could be viewed as exogenous. Since the final estimated equation was not the one initially used to test for endogeneity, it is reasonable to ask whether the decision to treat FEMEARN as exogenous would have still been made if the test had been performed on Regression 3. Repeating the test on this equation using the two alternative fitted series for FEM-EARN gave $t$-values ( $p$-values) of $1.70(0.097)$ and $1.74(0.090)$. Thus, the null hypothesis that FEM-EARN is exogenous was again not rejected at the $5 \%$ level of significance.

\section{Concluding Remarks}

Several empirical studies, not all at the aggregate level, have demonstrated a statistical causal relationship linking female earnings to divorce rates. Yet the literature examining possible simultaneity of these variables is comparatively meagre. Studies 
are also rare for countries other than the US and the United Kingdom. Using Australian data, in this paper we find that rising female earnings have partly contributed to the increase in divorce over the past four decades. These results join a large body of literature that is generally supportive of these findings and the economic theory. The paper also tests whether average female earnings and aggregate divorce rates are jointly endogenous, thus testing the robustness of the results of Ressler and Waters (2000). Their theory prescribing aggregate divorce rates as determinants of female earnings can be questioned. Increases in female earnings may be driven by factors other than divorce but which impact on both. One example is the presence of children. Also, the net effects of divorce on female earnings may cancel out at the aggregate level. Testing of the theory is ultimately an empirical question. The analysis provided in this paper is restricted by the use of aggregated data and limited observations. Nevertheless, it is demonstrated that divorce rates do not necessarily affect female earnings. This supports the hypothesis that rising divorce rates have had little or no influence on the steady increase in female earnings at the aggregate level. The finding is robust to minor model alterations; namely, whether or not state dummy variables are included when modelling female earnings.

Further research directed towards analysing relationships between such variables as fertility rates, female earnings, divorce and education within an enlarged data set is needed. In particular, an investigation using a micro data set would be appropriate. A thorough analysis of the interplay between education, children, divorce and earnings would require such highly detailed information. Of these relationships, perhaps the most illuminating would result from modelling differences in earnings between childless female divorcees and childless wives. This task is especially challenging for Australia given the lack of appropriate data at the micro level. 
Empirical studies of a greater pool of countries would also enhance understanding of the topic.

\section{Appendix}

$\underline{\text { Sources of data }}$

Divorces: Australian Bureau of Statistics (ABS), Marriages and Divorces, Canberra, 1995; 1999.

Nuptial births and fertility rates: CBCS, Victorian Yearbook, Canberra, 1963; 1968; 1973. ABS, Victorian Yearbook, Canberra, 1978; 1983._ABS, Births Australia, Canberra, 1987; 1992; 1997.

Female earnings and males earnings: CBCS, Survey of Weekly Earnings and Hours - Australia, October 1962; 1966; 1971. ABS, Earnings and Hours of Employees: Distribution and Composition, Canberra, May 1976; 1981. ABS, Distribution and Composition of Employee Earnings and Hours Australia, Canberra, May 1986; 1991. ABS, Employee Earnings and Hours Australia, Canberra, May 1996.

Proxy for 1996 occupations according to ASCO classifications: ABS, Labour Force Statistics, Canberra, August 1995.

Welfare payments: CBCS, New South Wales Yearbook, Canberra, 1965; 1968. Department of Social Security (DSS), Annual Report 1979-1980, Canberra, 1980. DSS, Annual Report 1991-92, Canberra, 1992. Department of Family and Community Services, Annual Report 199899, Canberra, 1999.

All other demographic statistics: Commonwealth Bureau of the Census and Statistics (CBCS) Census of the Commonwealth of Australia, 30 $0^{\text {th }}$ June, 1961, 
Volumes I-VI, Canberra, 1963. CBCS, 1966 Census, Volume 1: Population: Single Characteristics, Parts 1-11, Canberra, 1969. CBCS, 1971 Census, Bulletin 1: Summary of Population, Parts 1-6, Canberra, 1972. ABS, 1976 Census: Population and Dwellings: Summary Tables, Canberra, 1979. ABS, 1981 Census: Summary Characteristics of Persons and Dwellings, Canberra, 1983. ABS, 1986 Census: Summary Characteristics of Persons and Dwellings, Canberra, 1989. ABS, 1991 Census: Census Characteristics of States, Canberra, 1993. ABS, Census 1996: Selected Family and Labour Force Characteristics for Statistical Local Areas, Canberra, 1998. ABS, Census 1996: Selected Social and Housing Characteristics for Statistical Local Areas, Canberra, 1997.

\section{$\underline{\text { Calculating divorce rates }}$}

The ABS classifies divorces according to their state of registration, which is based on the location of the Family Court where the divorce is granted and registered. Divorces need to be measured by state of usual residence. Only for the years of 1993 and 1994 have divorce data been published by both state of residence and state of registration. For some states, there is a substantial discrepancy between these figures. To counter this problem, the following procedure was adopted. The ratio of divorces granted by state of usual residence to state of registration were calculated for 1993 and 1994, and averaged for each state. These state-specific ratios were then multiplied to the published divorce figures for every relevant year.

\section{$\underline{\text { Labour Force Calssifications }}$}

Prior to 1986, the Classification and Classified List of Occupations (CCLO) was used to code occupations. The Australian Standard Classification of Occupations (ASCO) replaced this system in 1986. A new method of categorising occupations was then 
introduced in 1996. Figures for each coding system are incomparable. Tables published in 1986 coded occupations according to both the ASCO and CCLO systems. These were used to obtain 1986 CCLO statistics. Furthermore, the number of workers in each CCLO grouping was calculated as some ratio of those in the ASCO grouping most closely resembling the CCLO job category. These ratios were multiplied to the ASCO figures for the most similar occupational grouping published in the 1991 Census and the August 1995 Labour Force publication. The latter source was used to proxy for possible 1996 ASCO statistics, to avoid similar problems adapting figures based on new classifications adopted in 1996. 


\section{References}

Allen, D.W. (1992) "Marriage and divorce: comment", American Economic Review, 82(3), pp679-85.

Becker, G. S. (1973) “A theory of marriage: Part I", Journal of Political Economy, 81(3), pp813-46.

Becker, G. S., Landes, E. M. and Michael, R. T. (1977) “An Economic Analysis of Marital Instability”, Journal of Political Economy, 85(6), pp1141-87.

Carmichael, G.A, Webster, A. and McDonald, P. (1996) "Divorce Australian Style: A Demographic Analysis”, Research School of Social Sciences: Working Papers in Demography, Australian National University, Canberra.

Gordon, J. and Robinson, P. (2001) “Average pay packet swells by extra $\$ 20$ ”, The Age, Friday August 17, 2001, p5.

Griffiths, W.E., Carter Hill R., and Judge, G.G. (1993) Learning and Practising Econometrics, John Wiley and Sons, USA.

Hoffman, S. D. and Duncan, G. J. (1995) "The effect of incomes, wages, and AFDC benefits on marital disruption", The Journal of Human Resources, 30(1), pp1941.

Johnson, W. R. and Skinner, J. (1986) “Labour supply and marital separation”, American Economic Review, 76(3), pp455-69.

Kidd, M. P. (1995) “The impact of legislation on divorce: a hazard function approach", Applied Economics, 27, pp125-130.

Maddala, G.S. (1992) Introduction to Econometrics (2 ${ }^{\text {nd }}$ ed), MacMillan, USA.

Pell, George. (2001) "We must save the family, or pay the price”, The Age, Friday August 24, 2001, p15. 
Peters, H. E. (1986) "Marriage and divorce: information constraints and private contracting", American Economic Review, 76(3), pp437-54.

Peters, H. (1992) "Marriage and divorce: reply", American Economic Review, 82(3), pp686-93.

Ressler, R. W. and Waters, M. S. (2000) "Female earnings and the divorce rate: a simultaneous equations model”, Applied Economics, 32, pp1889-98.

Sander, W. (1985) "Women, work and divorce", American Economic Review, 75(3), pp519-23.

Smith, I. (1997) "Explaining the growth of divorce in Great Britain", Scottish Journal of Political Economy, 44(5), pp519-544.

Sweezy, K. and Tiefenthaler, J. (1996) "Do state-level variables affect divorce rates?", Review of Social Economy, 54(1), pp47-65.

Wiess, Y. (1996) “The formation and dissolution of families: Why marry? Who marries whom? And what happens upon divorce?" in Rosenzweig, M.A. and Stark, O. (eds) Handbook and Population and Family Economics, Elsevier, Holland, 1996. 